\title{
Hepatitis B status in hemodialysis patients
}

\author{
Maia Nogueira Crown GUIMARÃES, Tila FACINCANI and Sigrid De Sousa dos SANTOS
}

Received 28/10/2016

Accepted 15/5/2017

ABSTRACT - Background - Patients on chronic dialysis present a high prevalence of hepatitis B virus infection. Despite infection-control practices, surveillance of serological markers, and hepatitis B vaccination, there are still outbreaks of the disease in dialysis centers. Objective - This study aims to assess the serologic and vaccination status for hepatitis B in hemodialysis patients. Methods - This cross-sectional study assessed serologic markers and hepatitis B vaccination status of chronic kidney disease patients on regular dialysis program in São Carlos, SP, Brazil. Patients without information about hepatitis B status (anti-HBc, HBsAg and anti-HBs) were referred for testing. Individuals with uncertain or incomplete immunization status and without serological conversion (anti-HBs $<10 \mathrm{mIU} / \mathrm{mL}$ ) were referred to vaccination, with adverse effects monitored. Results - The study included 130 from a total of 181 dialysis patients. The majority were male $(63.8 \%)$, mean age 53.9 years. All patients were already screened and negative for HBsAg, and 73.8\% were vaccinated against hepatitis B (59.2\% complete and $14.6 \%$ incomplete schedule), with a seroconversion rate of $75.3 \%$. Only $11(8.5 \%)$ patients had prior dosage of anti-HBc (negative). Among the 47 patients referred for anti-HBc testing, four were anti-HBc positive and one indeterminate. Of the total of patients referred to immunization, 34 have actually received HBV vaccine; among them five had mild adverse effects. Conclusion - Despite the benefit of dosing of anti-HBc and anti-HBs before admission to dialysis, economic constraints have reduced the screening to only HBsAg. Since occult HBV infection has already been demonstrated in hemodialysis patients, the measure of anti-HBc should be encouraged. HEADINGS - Hepatitis B. Health promotion. Chronic kidney disease. Hemodialysis. Vaccine. End-stage renal disease.

\section{INTRODUCTION}

Vaccination has reduced the risk of hepatitis B virus (HBV) infection in dialysis centers. Despite new infections are uncommon, outbreaks still happens in dialysis populations ${ }^{(21)}$. Transmission is associated to multi-dose vials and deficiencies in applying standard precautions ${ }^{(17)}$. Prevention is based on vaccination, segregation of HBsAg-positive patients and their equipment from HBV-susceptible patients, and general infection control practices ${ }^{(12)}$.

Hepatitis B in dialysis patients leans toward chronicity, with prominent fibrosis, little inflammation, silent clinical presentation and atypical serologic evolution ${ }^{(19)}$. Different studies have shown hepatitis B viral load relatively low and stable in dialysis patients. $\mathrm{HBeAg}$ is usually not detected, what shows an infrequent replicative phase of infection ${ }^{(13)}$.

Chronic kidney disease induces immune dysfunction, increases the susceptibility to infections and diminishes the response to vaccines $^{(16)}$. Patients should be vaccinated against HBV before dialysis commencement to obtain higher levels of anti-HBs antibodies ${ }^{(22)}$.

The HBV vaccine has been proven to be safe, with no evidence of relevant adverse effects. The main adverse events are local reactions such as pain, induration and erythema at the injection site; and mild systemic reactions such as fever, fatigue, headache and irritability $^{(4)}$.

The Brazilian Ministry of Health recommends routine HBV vaccination prior to dialysis with four doses of $40 \mu \mathrm{g}$ each, administered at $0,30,60$, and 180 days $^{(2,8)}$. Response to vaccine should be assessed one to two months after the last dose. Values of anti-HBs above $10 \mathrm{mIU} / \mathrm{mL}$ are considered protective. The requirement of booster doses should be assessed by annual testing for anti-HBs ${ }^{(8,10)}$. A booster dose should be administered when anti-HBs decline to less than $10 \mathrm{mIU} / \mathrm{mL}$. Every 3 to 6 months dialysis patients should be screened for hepatitis B through serology and liver enzymes ${ }^{(18,23)}$. The aim of this study was to assess the hepatitis B serologic profile and vaccine coverage in chronic hemodialysis patients.

\section{METHODS}

Cross-sectional study in adult patients with chronic kidney disease on regular dialysis program at the São Carlos Dialysis Service (Serviço de Nefrologia de São Carlos), São Carlos, SP, Brazil, August 2012 to March 2014. The Investigational Review Board of the Universidade Federal de São Carlos approved the study (CAAE00631012.0.0000.5504).

In order to assess the profiles of dialysis patients in São Carlos, total population sampling was used in the project. Hence, every adult patient (over 18 years old) on regular dialysis who agreed to participate and signed the consent form was included in the study.

Medical and immunization charts were reviewed during the hemodialysis sessions to access information on hepatitis B serological profile and vaccination status. Exclusively verbal information was ignored. Patients who have received hepatitis $\mathrm{B}$ vaccine in a 4-double dose schedule were considered to have completed the vaccination course. In the dialysis service, anti-HBs antibody levels were monitored annually and a booster dose of vaccine was routinely given to patients who had previously responded to the vaccine if their levels dropped below $10 \mathrm{mIU} / \mathrm{mL}$. Patients without information about previous dosage of anti-HBc, HBsAg and

Declared conflict of interest of all authors: none

Disclosure of funding: this work was partially supported by FAPESP (Fundação de Amparo à Pesquisa do Estado de São Paulo): grant 2013/16207-3 (MNCG) and grant 2013/16215-6 (TF). Departamento de Medicina, Universidade Federal de São Carlos, São Carlos, SP, Brasil.

Correspondence: Sigrid De Sousa dos Santos. Departamento de Medicina, Universidade Federal de São Carlos. Rodovia Washington Luis, Km 235 - CEP: $13.565-905$ - Caixa postal: 676 -

São Carlos - SP - Brasil. E-mail: sigridsantos@gmail.com.br, sigridsantos@ufscar.br 
anti-HBs were referred to dose it. Patients without previous vaccination, incomplete vaccination schedule or no serological conversion were referred to be vaccinated at the nearest health basic unit. Patients referred for vaccination were contacted either personally or by phone call to assess compliance with the vaccination and adverse effects within 30 days after vaccination.

Data were collected and analyzed using Epi Info ${ }^{\circledR} 3.5 .1$ software. Descriptive statistical analysis was performed. Patient characteristics were described, including HBV infection serological markers and vaccination.

\section{RESULTS}

This study evaluated the majority of patients on renal replacement therapy in São Carlos and region. In total, 130 were included in the study, from 181 dialysis patients. The region includes the municipalities of São Carlos (236,456 inhabitants), Ibaté $(32,810$ inhabitants), Porto Ferreira (54,056 inhabitants), Dourado (8,884 inhabitants) and Descalvado (32,595 inhabitants), amounting to a total of 364,802 inhabitants ${ }^{(5)}$. As the estimated prevalence of dialysis in Brazil is $0.05 \%$, the expected population of dialysis individuals in the region would be 182 patient $^{(3)}$. The majority of patients were male $(63.8 \%)$ with mean age of 53.9 years. The patients were on dialysis for a median time of 12 months (IQ4-48), with a median time of renal failure of 25 months (IQ8-84). A detailed description of study population was presented elsewhere ${ }^{(14)}$.

All patients have already been screened and were $\mathrm{HBsAg}$ negative (Table 1). Only 11 patients had prior dosage of anti-HBc (negative) because of transplant clinic screening, since this serological marker was not available in the dialysis service. Among the 119 patients without previous anti-HBc and referred for testing, just 47 attended the laboratory for blood collection, in which four were anti-HBc positive and one indeterminate. All these five patients have showed anti-HBs titers above $10 \mathrm{mIU} / \mathrm{mL}$.

TABLE 1. Hepatitis B characteristics of 130 dialysis patients at Serviço de Nefrologia de São Carlos

\begin{tabular}{lc}
\hline Characteristic & $\mathbf{n}(\%)$ \\
\hline Serological markers & \\
HBsAg & \\
$\quad$ Positive & $0(0)$ \\
$\quad$ Negative & $130(100)$ \\
Anti-HBc & \\
$\quad$ Positive & $4(3.1)$ \\
$\quad$ Negative* & $53(40.8)$ \\
Indeterminate & $1(0.8)$ \\
Not available & $72(55.4)$ \\
Anti-HBS & \\
$\quad \geq 10 \mathrm{mIU} / \mathrm{mL}$ & $73(56.1)$ \\
$\quad<10 \mathrm{mIU} / \mathrm{mL}$ & $53(40.8)$ \\
$\quad$ Not available & $4(3.1)$ \\
Hepatitis B vaccine status & \\
Complete (four double doses) & $77(59.2)$ \\
Incomplete & $19(14.6)$ \\
Not vaccinated & $12(9.2)$ \\
Ignored & $22(16.9)$ \\
\hline
\end{tabular}

* anti-HBc previously available in medical chart of 11 patients
Ninety-six patients were already vaccinated against hepatitis B (59.2\% complete and $14.6 \%$ incomplete schedule). The seroconversion rate among the 77 vaccinated patients was $75.3 \%$. Among the 72 patients without anti-HBc dosage even after protocol referral, 32 have not achieved protective titers of anti-HBS after immunization, three have no information on hepatitis B vaccine or anti-HBS, and one was not finished the vaccine schedule. Of the total of patients referred to immunization during the project, 34 have actually received $\mathrm{HBV}$ vaccine; among them five had mild local adverse effects.

\section{DISCUSSION}

The present study has found low anti-HBc screening and low hepatitis $\mathrm{B}$ vaccine coverage in dialysis patients. The dialysis centers have a strict protocol when it comes to the dosage of HBsAg: all patients should collect before the start of the first haemodialysis and every 1-6 months thereafter. The HBsAg prevalence $(0 \%)$ was compatible to that found in other dialysis populations in Brazil $(0 \% \text { to } 10 \%)^{(1,9,15)}$.

At the time of study, a policy of anti-HBc testing for every patient on dialysis has not yet been implemented. The patients with available anti-HBc had dosed it in kidney transplantation centers. It is unclear the real risk of transmission of hepatitis B in these patients ${ }^{(11)}$. The anti-HBc prevalence rate in dialysis populations in Brazil has varied from $23.2 \%$ to $29.7 \%{ }^{(1,9,15)}$. Among the 58 patients tested for anti-HBc, $6.9 \%$ were positive or undetermined. The major risk of not monitoring anti-HBc in dialysis patients is the possibility of occult hepatitis $\mathrm{B}$, with potential reactivation during periods of immunosuppression. The prevalence of occult hepatitis B infection in dialysis patients with anti-HBc positive varies from $1.5 \%$ to $44.7 \%{ }^{(1,11)}$. Thus, Anti-HBc can be used as a marker for identifying patients with a higher risk of occult hepatitis $\mathrm{B}$, although it is far from an ideal marker ${ }^{(20)}$.

After the end of this protocol, the Brazilian Ministry of Health launched the guideline "Diretrizes Clínicas para o Cuidado ao Paciente com Doença Renal Crônica no Sistema Único de Saúde", which included anti-HBc dosage at the beginning of dialysis. However it still maintains only HBsAg in semiannual monitoring ${ }^{(6)}$. The dosage of anti-HBc depends on the availability of these tests in dialysis centers, since these patients have limited mobility.

We observed a difficulty of the dialysis center in referring patients for vaccination before starting dialysis. Although in southeastern Brazil hemodialysis accounts for only $0.9 \%$ of transmission of hepatitis $\mathrm{B}^{(7)}$, a greater compliance with the recommended hepatitis B vaccine schedule would increase the seroconversion rate, reducing the risk of outbreaks.

\section{ACKNOWLEDGEMENTS}

We would like to thank Dr Afonso de Souza Thadeu Pannacci and Dr. Fabrizio Margarido Albertini from Serviço de Nefrologia de São Carlos, and Blaranis Helena Paulletto from Centro Municipal de Especialidades de São Carlos. We would also like to acknowledge the help of Andrea Ferraz de Oliveira Cruz in the study design and collection of data.

\section{Authors' contributions}

Guimarães MNC, Facincani T, Santos SS conceived this study, participated in its design, performed the data collection and statistical analysis, and drafted the manuscript. All authors read and approved the final manuscript. 
Guimarães MNC, Facincani T, Santos SS. Situação da hepatite B em pacientes em hemodiálise. Arq Gastroenterol. 2017;54(4):356-8.

RESUMO - Contexto - Pacientes cronicamente em diálise apresentam alta prevalência de infecção por vírus da hepatite B. Apesar de práticas de controle de infecção, vigilância de marcadores sorológicos e vacinação contra a hepatite B, ainda há surtos da doença em centros de diálise. Objetivo - Este estudo tem como objetivo avaliar o estado sorológico e a vacinação contra hepatite B em pacientes em hemodiálise. Métodos - Estudo transversal avaliando marcadores sorológicos e vacinação contra a hepatite B em pacientes com doença renal crônica em programa regular de hemodiálise em São Carlos, SP, Brasil. Pacientes sem marcadores sorológicos para hepatite B disponíveis (anti-HBc, HBsAg e anti-HBs) foram encaminhados para testagem. Em caso de situação vacinal desconhecida, incompleta ou sem resposta vacinal (anti-HBs $<10 \mathrm{mIU} / \mathrm{mL}$ ), os pacientes foram encaminhados para vacinação, sendo os efeitos adversos monitorados. Resultados - O estudo incluiu 130 de um total de 181 pacientes em diálise. A maioria era do sexo masculino (63,8\%), com idade média de 53,9 anos. Todos os pacientes já haviam sido rastreados e eram negativos para $\mathrm{HBs} \mathrm{Ag}$, e $73,8 \%$ foram vacinados contra a hepatite B (59,2\% esquema completo e 14,6\% esquema incompleto), com uma taxa de soroconversão de $75,3 \%$. Apenas 11 ( $8,5 \%)$ pacientes dispunham de dosagem prévia de anti-HBc (negativo). Entre os 47 pacientes encaminhados para testagem anti-HBc, quatro eram anti-HBc reagentes e um indeterminado. Do total de pacientes encaminhados à imunização, 34 receberam efetivamente a vacina contra o HBV; entre eles, cinco tiveram efeitos adversos leves. Conclusão - Apesar do benefício da dosagem de anti-HBc e anti-HBs antes da admissão à diálise, restrições econômicas reduziram o rastreio apenas à dosagem de HBsAg. Como a infecção oculta por HBV já foi demonstrada em pacientes em hemodiálise, a dosagem de anti-HBc deve ser incentivada.

DESCRITORES - Hepatite B. Promoção da saúde. Doença renal crônica. Hemodiálise. Vacina. Falência renal crônica.

\section{REFERENCES}

1. Albuquerque AC, Coelho MR, Lemos MF, Moreira RC. Occult hepatitis B virus infection in hemodialysis patients in Recife, State of Pernambuco, Brazil. Rev Soc Bras Med Trop. 2012;45:558-62.

2. Ayub MA, Bacci MR, Fonseca FL, Chehter EZ. Hemodialysis and hepatitis B vaccination: a challenge to physicians. Int J Gen Med. 2014;7:109-14.

3. Brasil. Censo de diálise SBN 2013. In: Nefrologia SBd, editor; 2013.

4. Brasil. Divisão de Imunização. Divisão de Hepatites. Centro de Vigilância Epidemiológica "Prof. Alexandre Vranjac". Coordenadoria de Controle de Doenças. Secretaria de Estado da Saúde de São Paulo - DI/DH/CVE/CCD/SES-SP. Vacina contra hepatite B [Hepatitis B vaccine]. Rev Saude Publica. 2006;40:1137-40.

5. Brasil. Infográficos. In: IBGE, editor. Instituto Brasileiro de Geografia e Estatística. Rio de Janeiro; 2014.

6. Brasil. Ministério da Saúde. Secretaria de Atenção à Saúde. Departamento de Atenção Especializada e Temática. Diretrizes clínicas para o cuidado ao paciente com doença renalcrônica - DRC no Sistema Único de Saúde. Brasília - DF: Ministério da Saúde; 2014.

7. Brasil. Ministério da Saúde. Secretaria de Vigilância em Saúde - Departamento de DST, Aids e Hepatites Virais. Boletim Epidemiológico - Hepatites Virais. Brasília: Ministério da Saúde; 2012.

8. Brasil. Ministério da Saúde/SVS/DVE. Manual dos centros de referência para imunobiológicos especiais. Brasilia: Ministério da Saúde; 2006.

9. Carrilho FJ, Moraes CR, Pinho JR, et al. Hepatitis B virus infection in Haemodialysis Centres from Santa Catarina State, Southern Brazil. Predictive risk factors for infection and molecular epidemiology. BMC Public Health. 2004;4:13.

10. Chi C, Patel P, Pilishvili T, Moore M, Murphy T, Strikas R. Guidelines for Vaccinating Dialysis Patients and Patients with Chronic Kidney Disease In: Department of Health and Human Services U, CDC, editors.: Advisory Committee on Immunization Practices (ACIP); 2012. p. 12
11. Di Stefano M, Volpe A, Stallone G, et al. Occult HBV infection in hemodialysis setting is marked by presence of isolated antibodies to $\mathrm{HBcAg}$ and $\mathrm{HCV}$. J Nephrol. 2009;22:381-6.

12. Edey M, Barraclough K, Johnson DW. Review article: Hepatitis B and dialysis. Nephrology (Carlton). 2010;15:137-45

13. Fabrizi F, Lunghi G, Alongi G, et al. Biological dynamics of hepatitis B virus load in dialysis population. Am J Kidney Dis. 2003;41:1278-85.

14. Facincani T, Guimarães MN, De Sousa Dos Santos S. Yellow fever vaccination status and safety in hemodialysis patients. Int J Infect Dis. 2016;48:91-5.

15. Ferreira RC, Teles SA, Dias MA, et al. Hepatitis B virus infection profile in hemodialysis patients in Central Brazil: prevalence, risk factors, and genotypes. Mem Inst Oswaldo Cruz. 2006;101:689-92.

16. Kato $\mathrm{S}$, Chmielewski $\mathrm{M}$, Honda $\mathrm{H}$, et al. Aspects of immune dysfunction in end-stage renal disease. Clin J Am Soc Nephrol. 2008;3:1526-33.

17. Lanini S, Puro V, Lauria FN, Fusco FM, Nisii C, Ippolito G. Patient to patient transmission of hepatitis B virus: a systematic review of reports on outbreaks between 1992 and 2007. BMC Med. 2009;7:15.

18. Leehey DJ, Cannon JP, Lentino JR. Infecções. In: Daugirdas JT, Blake PG, Ing TS, eds. Manual de Diálise. 4 ed ed. São Paulo: Guanabara Koogan. 2008:500-28.

19. Molino C, Fabbian F, Cozzolino M, Longhini C. The management of viral hepatitis in CKD patients: an unresolved problem. Int J Artif Organs. 2008;31:683-96

20. Raimondo G, Allain JP, Brunetto MR, et al. Statements from the Taormina expert meeting on occult hepatitis B virus infection. J Hepatol. 2008;49:652-7.

21. Recommendations for preventing transmission of infections among chronic hemodialysis patients. MMWR Recomm Rep. 2001;50(RR-5):1-43.

22. Remuzzi G, Schieppati A, Minetti L. Hematologic Consequences of Renal Failure. In: Brenner BM, ed. The kidney. 17 ed. Philadelphia: Saunders. 2004:2178-80.

23. Unger JK, Peters H. Hepatitis B in chronic kidney disease: moving toward effective prevention. Kidney Int. 2008;73:799-801. 